\title{
5-Hydroxymethylcytosine is associated with enhancers and gene bodies in human embryonic stem cells
}

\author{
Hume Stroud ${ }^{1}$, Suhua Feng ${ }^{1,2}$, Shannon Morey Kinney ${ }^{3}$, Sriharsa Pradhan ${ }^{3}$ and Steven E Jacobsen ${ }^{1,2^{*}}$
}

\begin{abstract}
Background: 5-Hydroxymethylcytosine $(5 \mathrm{hmC})$ was recently found to be abundantly present in certain cell types, including embryonic stem cells. There is growing evidence that TET proteins, which convert 5-methylcytosine $(5 \mathrm{mC})$ to $5 \mathrm{hmC}$, play important biological roles. To further understand the function of $5 \mathrm{hmC}$, an analysis of the genome-wide localization of this mark is required.

Results: Here, we have generated a genome-wide map of $5 \mathrm{hmC}$ in human embryonic stem cells by hmeDIP-seq, in which hydroxymethyl-DNA immunoprecipitation is followed by massively parallel sequencing. We found that $5 \mathrm{hmC}$ is enriched in enhancers as well as in gene bodies, suggesting a potential role for $5 \mathrm{hmC}$ in gene regulation. Consistent with localization of $5 \mathrm{hmC}$ at enhancers, $5 \mathrm{hmC}$ was significantly enriched in histone modifications associated with enhancers, such as H3K4me1 and H3K27ac. 5hmC was also enriched in other protein-DNA interaction sites, such as OCT4 and NANOG binding sites. Furthermore, we found that $5 \mathrm{hmC}$ regions tend to have an excess of $\mathrm{G}$ over $\mathrm{C}$ on one strand of DNA.
\end{abstract}

Conclusions: Our findings suggest that $5 \mathrm{hmC}$ may be targeted to certain genomic regions based both on gene expression and sequence composition.

\section{Background}

Cytosine DNA methylation (5-methylcytosine $(5 \mathrm{mC})$ ) is an epigenetic mark that is widespread in both animals and plants, and appears to play important roles in various biological processes, such as gene silencing and imprinting. Recently, studies have shown that embryonic stem cells (ESCs) and Purkinje neurons contain high levels of 5-hydroxymethylcytosine $(5 \mathrm{hmC})[1,2]$. Human TET1, a 2-oxoglutarate- and $\mathrm{Fe}(\mathrm{II})$-dependent enzyme, has been shown to catalyze the conversion of $5 \mathrm{mC}$ to $5 \mathrm{hmC}$ both in vitro and in vivo [1]. Subsequently, all mouse Tet proteins, Tet1, Tet2 and Tet3, were shown to be able to convert $5 \mathrm{mC}$ to $5 \mathrm{hmC}$ [3]. Disruption in human TET1 and TET2 is associated with diseases such as MLL-associated leukemia [4] and myeloproliferative disorders [5]. Studies have suggested that $5 \mathrm{hmC}$ inhibits the methyl-CpG-binding protein $\mathrm{MeCP} 2$ from binding DNA [6]. In addition to

\footnotetext{
* Correspondence: jacobsen@ucla.edu

'Department of Molecular, Cell and Developmental Biology, University of California, Los Angeles, Los Angeles, CA 90095, USA

Full list of author information is available at the end of the article
}

the exclusion of methyl-CpG-binding proteins, $5 \mathrm{hmC}$ may recruit unknown $5 \mathrm{hmC}$ binding protein(s). Moreover, because the DNA methyltransferase DNMT1 binds poorly to $5 \mathrm{hmC}[1,7]$, it is possible that $5 \mathrm{hmC}$ plays a role in excluding DNMT1 from methylating cytosines and thus may promote DNA demethylation. Importantly, $5 \mathrm{hmC}$ diminishes as embryonic stem cells (ESCs) differentiate, suggesting that $5 \mathrm{hmC}$ may play specific roles in ESCs. Indeed, mouse Tet1 has been shown to be required for ESC maintenance [3]. The function of $5 \mathrm{hmC}$ in mammals remains poorly understood. To further understand the role of $5 \mathrm{hmC}$, it is necessary to understand where $5 \mathrm{hmC}$ localizes in the genome. Very recently, a genomewide map of $5 \mathrm{hmC}$ was reported in mouse cerebellum [8]. $5 \mathrm{hmC}$ was chemically tagged and affinity enriched, and the purified DNA was sequenced. The authors found that $5 \mathrm{hmC}$ is enriched over genes and is positively correlated with expression levels [8].

Recently, commercial antibodies specific to $5 \mathrm{hmC}$ have become available. While these antibodies specifically recognize $5 \mathrm{hmC}$, it is important to note that they
C Biomed Central

() 2011 Stroud et al.; licensee BioMed Central Ltd. This is an open access article distributed under the terms of the Creative Commons Attribution License (http://creativecommons.org/licenses/by/2.0), which permits unrestricted use, distribution, and reproduction in any medium, provided the original work is properly cited. 
tend to prefer densely 5 -hydroxymethylated sites to single $5 \mathrm{hmC}$ sites (Figure S1 in Additional file 1). Here we generated genome-wide maps of $5 \mathrm{hmC}$ in human ESCs (hESCs) by performing hydroxymethyl-DNA immunoprecipitation followed by massively parallel sequencing with an Illumina Genome Analyzer (hmeDIP-seq). As did Song et al. [8], we found that a large fraction of $5 \mathrm{hmC}$ peaks were enriched over genes. However, we also found that $5 \mathrm{hmC}$ is enriched over predicted hESC enhancers, further suggesting a potential role of $5 \mathrm{hmC}$ in gene regulation. Moreover, we observed enrichment of $5 \mathrm{hmC}$ peaks with transcription binding sites such as those of pluripotency factors OCT4 and NANOG. In addition, we found that $5 \mathrm{hmC}$ regions correspond to genomic regions that are GC-skewed.

\section{Results and discussion}

\section{$5 \mathrm{hmC}$ is enriched over genic regions}

To generate genome-wide maps of $5 \mathrm{hmC}$, we performed two hmeDIP-seq experiments using two different commercial antibodies (Active Motif and Diagenode). HmeDIP-seq experiments generated 10 to 30 million reads that uniquely mapped to the human genome (Figure 1a). We defined regions for both maps by using both input DNA and 'no antibody' sequencing reads as background controls (see Materials and methods). We selected 15,324 regions that were called significant in both hmeDIP-seq experiments. The average length of the defined regions was $1.5 \mathrm{~kb}$, and consistent with previous findings with chemically labeling methods [8], sex chromosomes were depleted in $5 \mathrm{hmC}$ regions (Figure S2a-c in Additional file 1).

The chromosomal distribution of $5 \mathrm{hmC}$ regions suggested that $5 \mathrm{hmC}$ is within gene-rich chromosomal domains (Figure $1 \mathrm{~b}$ ). Indeed, $46.2 \%$ of defined $5 \mathrm{hmC}$ regions overlapped with RefSeq annotated genes, suggesting a potential role of $5 \mathrm{hmC}$ in gene regulation. Plotting $5 \mathrm{hmC}$ peaks over RefSeq genes, we found that $5 \mathrm{hmC}$ tends to localize to transcribed regions (bodies) of genes in addition to immediate upstream regions (Figure S3a in Additional file 1). The distribution of expression levels of genes with $5 \mathrm{hmC}$ peaks was similar to levels of all genes, suggesting that $5 \mathrm{hmC}$ may not linearly correlate with expression levels (Figure S3b in Additional file 1). Plotting the distribution of $5 \mathrm{hmC}$ peaks over RefSeq genes with different expression levels, we observed that $5 \mathrm{hmC}$ is enriched near the transcription start sites of lowly expressed genes, whereas $5 \mathrm{hmC}$ is depleted at transcription start sites of highly expressed genes (Figure 1c). This is in contrast to data reported by Song et al. [8] that suggested that $5 \mathrm{hmC}$ levels positively correlate with expression in mouse cerebellum, suggesting possible differences in the role of $5 \mathrm{hmC}$ in different tissues.

\section{$5 \mathrm{hmC}$ is enriched over enhancers}

Because a large proportion of $5 \mathrm{hmC}$ peaks did not fall into genic regions, we examined whether $5 \mathrm{hmC}$ co-localized with predicted enhancers in hESCs [9]. Indeed, we found that $5 \mathrm{hmC}$ peaks were highly enriched over enhancers (Figure 2a), and the magnitude of enrichment was greater than that observed over genes. We found that 3,028 enhancers overlapped with $5 \mathrm{hmC}$ peaks. $5 \mathrm{hmC}$ enrichment at enhancers was verified using a method that can measure $5 \mathrm{hmC}$ levels at CCGG sites by glucosylating $5 \mathrm{hmC}$ and digesting with the MspI restriction enzyme (MspI can digest $5 \mathrm{hmC}$, but not glucosylated $5 \mathrm{hmC}$ ) [10] (Figure 2b). Quantitative PCR assays across selected CCGG sites suggested that $5 \mathrm{hmC}$ levels at tested $5 \mathrm{hmC}$ peaks ranged from $9.6 \%$ to $36.4 \%$, whereas at control regions the levels ranged from $0.5 \%$ to $2.7 \%$. Enhancers are marked by chromatin signatures such as histone $\mathrm{H} 3$ lysine 4 monomethylation (H3K4me1) and histone $\mathrm{H} 3$ lysine 27 acetylation (H3K27ac) [11]. We confirmed that $5 \mathrm{hmC}$ peaks significantly overlapped with defined H3K4me1 and H3K27ac regions from a separate study [12] (Figure 2c), and 5hmCmarked enhancers overlapped with both of these marks to a greater extent compared to all predicted enhancers (Figure $2 \mathrm{~d}$ ). Remarkably, we observed positive correlations between $5 \mathrm{hmC}$ and H3K4me1 and H3K27ac despite comparing data from different cell lines. We next tested whether $5 \mathrm{hmC}$ marks active or poised enhancers [12], and found that $5 \mathrm{hmC}$ is more likely associated with active enhancers (Figure S4a, b in Additional file 1). Because enhancers regulate gene expression in a cell-type-specific manner [11], we sought to test whether genes specifically expressed in hESCs are associated with $5 \mathrm{hmC}$. We defined the genes closest to each given $5 \mathrm{hmC}$ peak (measured from transcription start sites; maximum distance allowed = $100 \mathrm{~kb}$ ) as $5 \mathrm{hmC}$-regulated genes. We next defined hESCspecific expressed genes by using a published RNA-seq data set (H1 hESCs versus IMR-90 fibroblast cells) [9] and only selecting genes that were expressed in hESCs (reads per kilobase of exon model per million mapped reads $($ RPKM $) \geq 0.5)$ and silent in IMR-90 cells $(R P K M=0)$. Interestingly, we found that $42.5 \%$ of hESC-specific expressed genes overlapped with $5 \mathrm{hmC}$ peaks, whereas $27.5 \%$ of all genes overlapped with $5 \mathrm{hmC}$ peaks $(P<$ 0.0001; Figure 2e). Hence, in hESCs, $5 \mathrm{hmC}$ shows some preference for genes specifically expressed in hESCs. This is consistent with results from previous studies suggesting that predicted enhancers from a particular cell-type mark cell-specific expressed genes [11].

To examine whether $5 \mathrm{hmC}$ peaks are associated with genes with specific functions, we performed gene ontology analyses using GREAT [13], which enables functional analysis of cis-regulatory regions such as enhancers. Interestingly, $5 \mathrm{hmC}$-associated genes tended to function in processes such as embryonic pattern 
(a) $\downarrow$

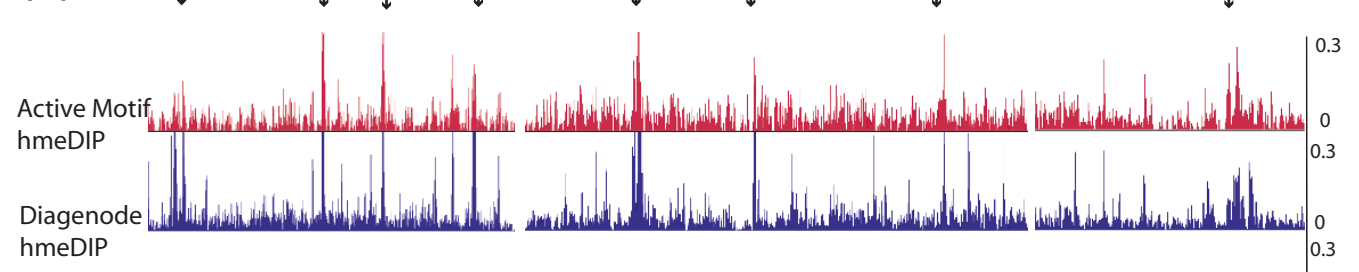



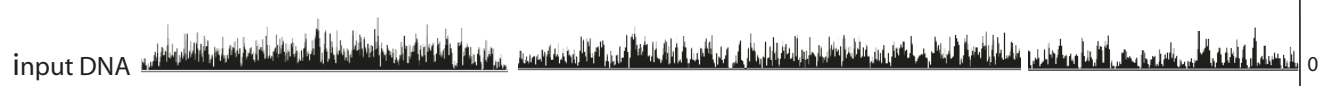

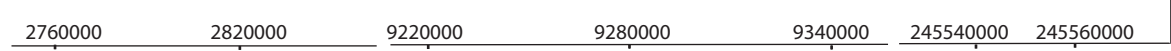

(b)


(c)
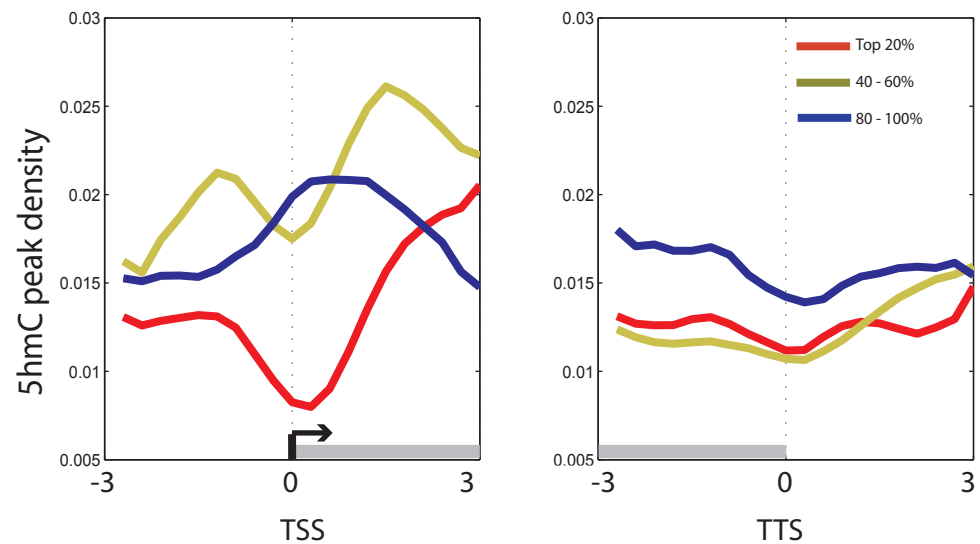

Figure 1 High resolution map of hydroxymethylcytosine in human embryonic stem cells. (a) Genome-browser view of hmeDIP-seq data. Two hmeDIP-seq datasets along with input DNA and 'no antibody' controls are shown. Each track is represented as normalized density of reads (reads/bp/million uniquely mapping reads). (b) Gene density (genes/bp) and $5 \mathrm{hmC}$ peak density (peaks/bp) in chromosome 3. (c) $5 \mathrm{hmC}$ over genes with different expression levels. $5 \mathrm{hmC}$ peak density was plotted over RefSeq genes in 300-bp bins. Plots were smoothed by taking the moving average over \pm 2 bins. Published RNA sequencing data [9] were used to rank the genes. TSS, transcription start site; TTS, transcription termination site. 
(a)



(c)



-5hmC peaks $(\mathrm{N}=15324) \quad$ RANDOM regions $(\mathrm{N}=15324)$

(b)

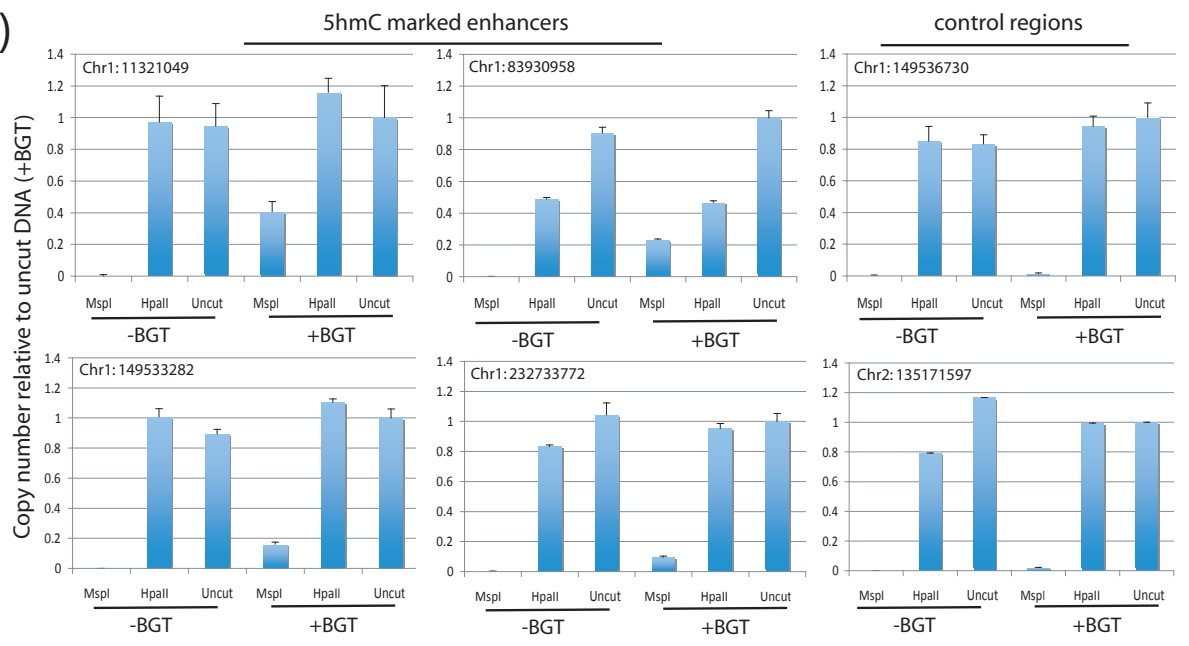

(d)

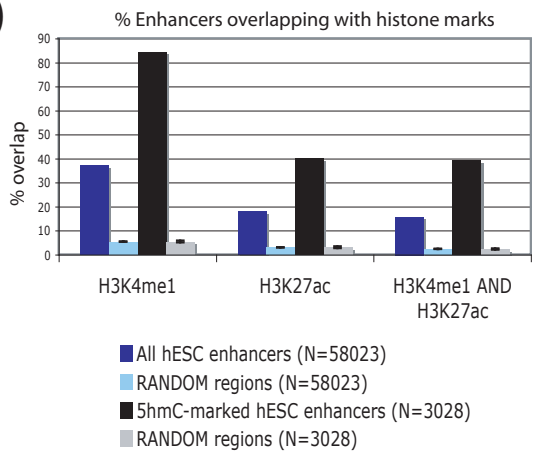

(e)

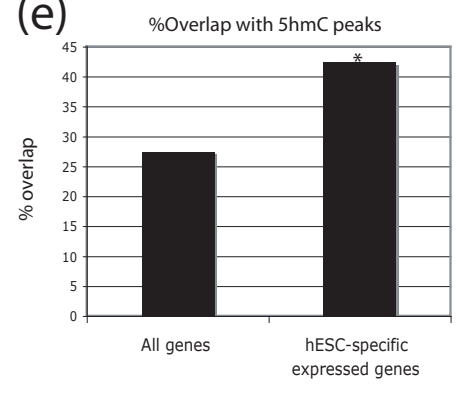

Figure 2 Co-localization of $\mathbf{5 h m C}$ with enhancers. (a) $5 \mathrm{hmC}$ over enhancers in hESCs. $5 \mathrm{hmC}$ peak density was plotted over predicted hESC enhancers $[9,21]$ in 100-bp windows. (b) Verfication of $5 \mathrm{hmC}$ at enhancers by measuring $5 \mathrm{hmC}$ levels at CCGG sites. Four $5 \mathrm{hmC}$ peaks at enhancers and two control regions were tested. Mspl cannot cut glucosylated-5hmC but is able to cut $5 \mathrm{hmC}$; therefore, copy numbers of Mspl + beta-glucosyltransferase (BGT) represent $5 \mathrm{hmC}$ levels. On the other hand, Hpall can only cut unmodified DNA; therefore, copy numbers represent $5 \mathrm{hmC}+5 \mathrm{mC}$ levels. Background signal was subtracted from the copy number of each sample and then normalized to the undigested glucosylated sample. Genomic locations of tested cytosines are indicated. Error bars represent the standard deviation. (c) Histone modifications over $5 \mathrm{hmC}$ peaks. The overlap of $5 \mathrm{hmC}$ peaks with previously defined H3K4me1- and H3K27ac-enriched regions [12] was calculated. Random regions with the same number and size distribution as $5 \mathrm{hmC}$ peaks were generated and overlap with histone modifications was calculated 100 times. Error bars represent standard deviation. (d) Histone modifications over 5hmC-marked enhancers. Predicted enhancers that overlapped with $5 \mathrm{hmC}$ peaks were selected. The overlap of these $5 \mathrm{hmC}$-marked enhancers, as well as all predicted enhancers, with previously defined H3K4me1 and H3K27ac enriched regions [12] was calculated. Random regions with the same number and size distribution as the enhancers were generated and overlap with histone modifications was calculated 100 times. Error bars represent standard deviation. (e) hESC-specific expressed genes significantly overlap with $5 \mathrm{hmC}$ peaks. hESC-specific genes were defined as genes that were expressed in hESCS (reads per kilobase of exon model per million mapped reads $(\mathrm{RPKM}) \geq 0.5)$ and silent in IMR90 cells $(\mathrm{RPKM}=0)$ using published RNA-seq data [9]. $* P<0.0001$. 
specification, cerebellum morphogenesis, and other developmental processes (Figure S5 in Additional file 1).

\section{$5 \mathrm{hmC}$ is enriched over transcription factor binding sites}

Because predicted enhancers of ESCs are enriched in some known ESC-specific transcription factors [11], we next examined the overlap of $5 \mathrm{hmC}$ with previously identified transcription factor binding sites (TFBSs) in hESCs [14]. Interestingly, we found that $5 \mathrm{hmC}$ regions were enriched over pluripotency factors NANOG and OCT4 binding sites, as well as the sites of insulator binding protein CTCF (Figure 3a-c). This result, along with the fact that $5 \mathrm{hmC}$ is enriched over enhancers, suggests that $5 \mathrm{hmC}$ may mark protein-DNA interaction sites. Visual inspection of certain hESC-specific genes [15] further confirmed overlaps between $5 \mathrm{hmC}$ and loci such as enhancers and TFBSs (Figure S6a,b in Additional file 1). Bisulfite sequencing and methylation-sensitive restriction digestion methods, both techniques that cannot distinguish $5 \mathrm{mC}$ and $5 \mathrm{hmC}$, have suggested that DNA methylation levels are reduced at TFBSs and enhancers $[9,12]$. Because we observed enrichment of $5 \mathrm{hmC}$ at these sites, it is likely that the low levels of DNA methylation observed by the previous studies are at least in part $5 \mathrm{hmC}$. This suggests that $5 \mathrm{mC}$ levels may be even lower than previously measured by bisulfite sequencing and methylation-sensitive restriction digestion methods. It is plausible to hypothesize that $5 \mathrm{mC}$ blocks enhancer proteins and transcription factors from binding DNA. On the contrary, $5 \mathrm{hmC}$ inhibits both the DNA methyltransferase DNMT1 and the methyl-CpG-binding protein $\mathrm{MeCP} 2$ from binding $[1,6,7]$. Hence, $5 \mathrm{hmC}$ may function in negatively regulating $5 \mathrm{mC}$ levels at certain proteinDNA interaction sites in order to allow protein-DNA binding of enhancer proteins and transcription factors.

\section{$5 \mathrm{hmC}$ regions are GC-skewed}

We next examined the sequence contexts associated with $5 \mathrm{hmC}$. By plotting the frequencies of nucleotides, we observed that $5 \mathrm{hmC}$ regions are enriched in GC content (Figure 4a, b). Furthermore, curiously, we found that $5 \mathrm{hmC}$ regions are $\mathrm{GC}$-skewed, where Gs are enriched over Cs in the 5' ends of the regions, whereas the 3' ends of the regions had the opposite skew, where Cs are enriched over Gs (Figure 4a, b). The GC-skew was observed in $5 \mathrm{hmC}$ regions overlapping with genes and enhancers as well as $5 \mathrm{hmC}$ regions not overlapping with these elements, suggesting that this sequence composition is a common feature of all $5 \mathrm{hmC}$ regions (Figure S7a-c in Additional file 1). Hence, $5 \mathrm{hmC}$ may be targeted to $\mathrm{GC}$ skew regions. Because changes in the sign of GC-skew (from $\mathrm{G}$ rich to $\mathrm{C}$ rich) is thought to occur at sites of replication termination [16-18] as well as recombination hotspots [19], a speculation is that $5 \mathrm{hmC}$ may also mark termination sites of DNA

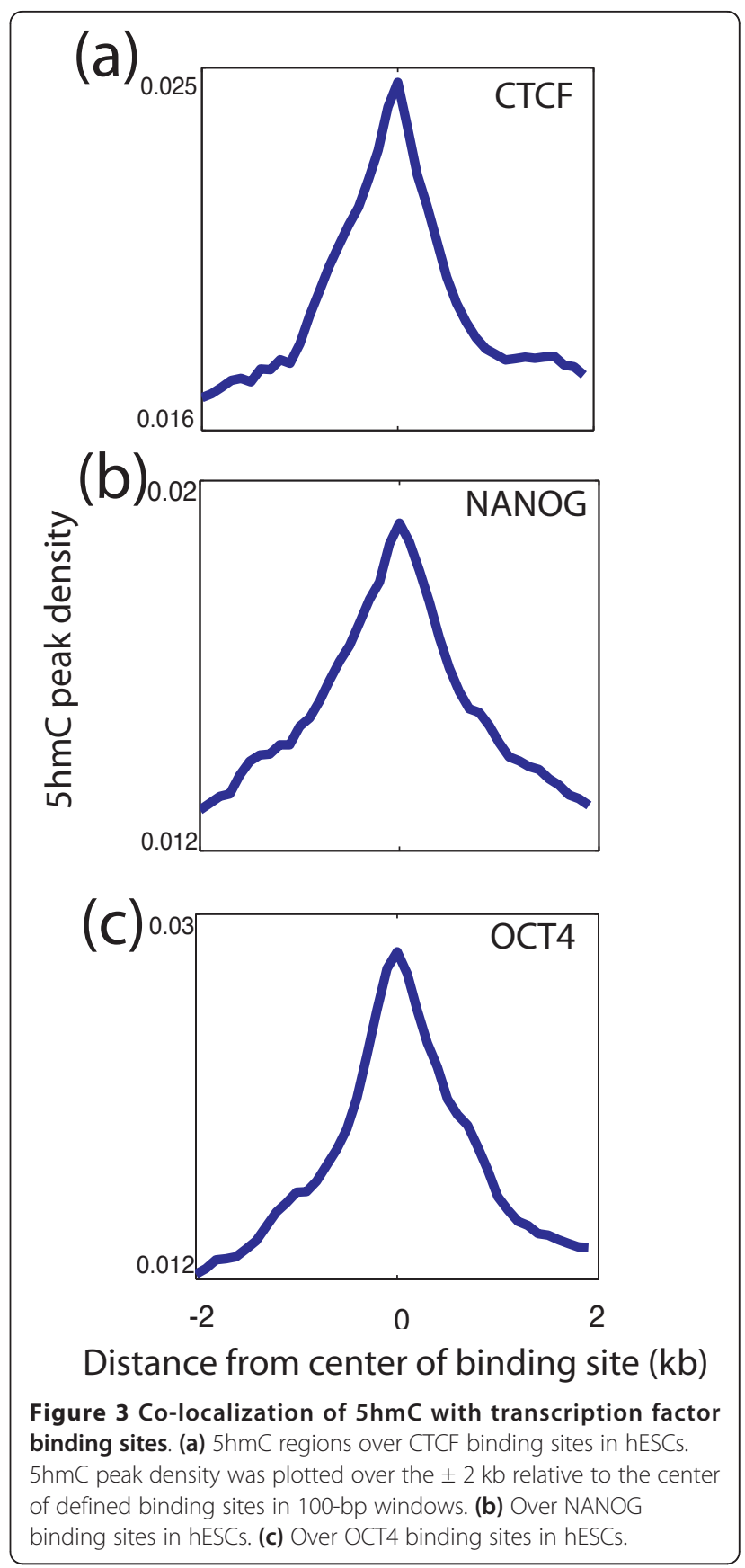

replication or sites of recombination. With the same reasoning that $5 \mathrm{hmC}$ may mark sites of protein-DNA binding, such as enhancers and transcription factors, an attractive hypothesis is that $5 \mathrm{hmC}$ may allow binding of factors of replication or recombination.

\section{Conclusions}

We have generated the first genome-wide map of $5 \mathrm{hmC}$ in $\mathrm{hESCs}$, and have found that $5 \mathrm{hmC}$ localizes to enhancers and gene bodies. $5 \mathrm{hmC}$ also tended to localize to other 

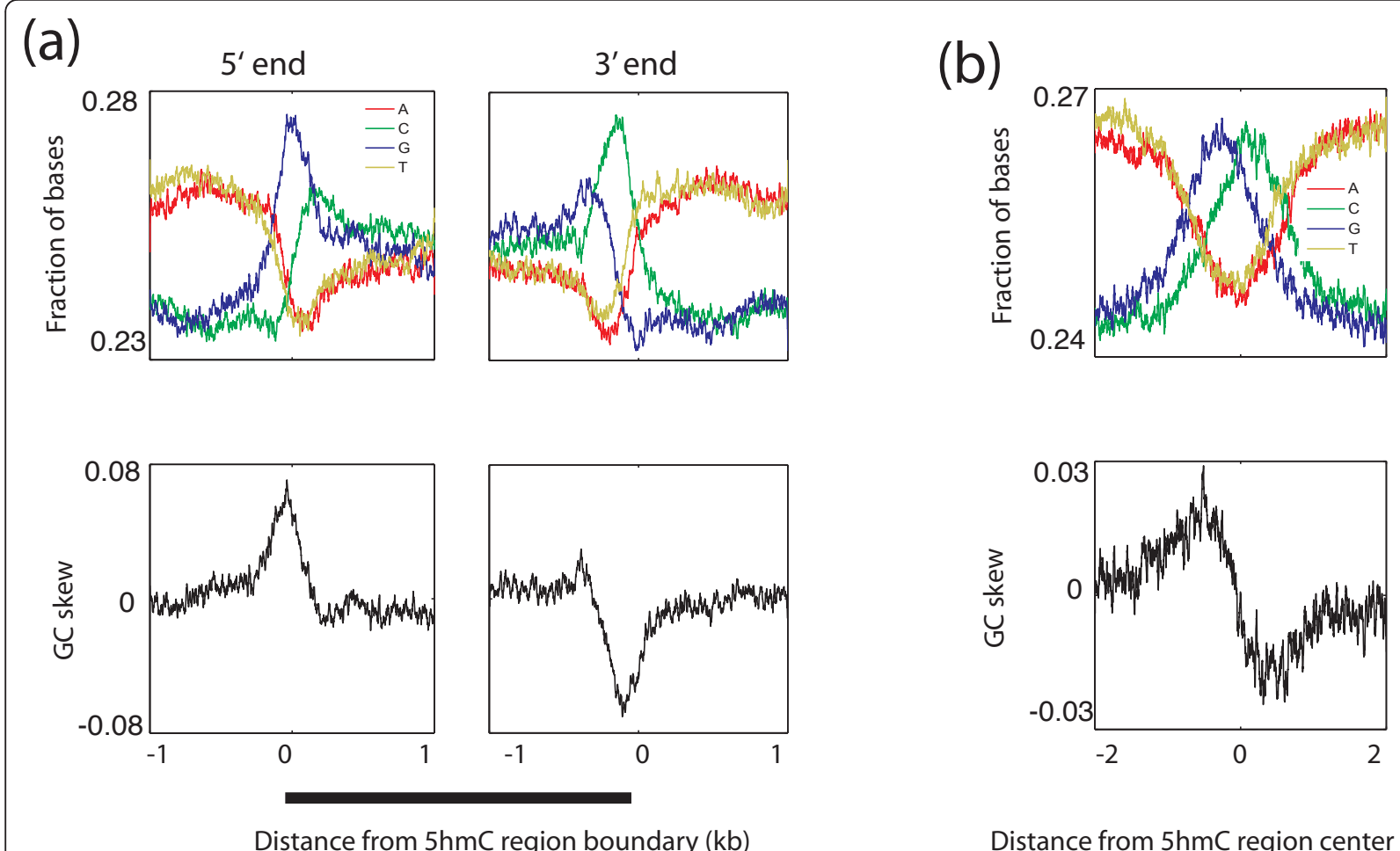

Figure $45 \mathrm{hmC}$ regions are GC-skewed. (a) Base composition of the Watson strand over the $5^{\prime}$ and $3^{\prime}$ boundaries of $5 \mathrm{hmC}$ regions. GC-skew $=$ absolute value $(G-C) /(G+C)$. (b) Base composition of the Watson strand over the centers of $5 \mathrm{hmC}$ regions.

protein-DNA interaction sites such as TFBSs, suggesting a role of $5 \mathrm{hmC}$ in gene regulation. Finally, we found a novel characteristic of the DNA sequences associated with $5 \mathrm{hmC}$ peaks, GC-skew, which suggests the possibility that sequence composition may be a signal for the deposition of this epigenetic mark.

\section{Materials and methods}

Hydroxymethyl-DNA immunoprecipitation and Illumina library generation/sequencing

hmeDIP experiments were performed on HSF1 hESCs as previously described [20] using commercial antibodies specific to $5 \mathrm{hmC}$, except that Illumina adapter ligated DNA fragments were used as the input for the immunoprecipitation. Two experiments, one using rabbit polyclonal antibody (Active Motif, Carlsbad, CA, USA) and the other using mouse monoclonal antibody (Diagenode, Sparta, NJ, USA), were performed using $5 \mu \mathrm{g}$ per immunoprecipitation. Input genomic DNA and no antibody controls were also kept for sequencing. Illumina libraries were generated and sequenced on an Illumina Genome Analyzer per the manufacturer's instructions.

\section{Data processing and analysis}

Sequenced reads were base-called using the standard Illumina software. Reads were trimmed down to 50 bases due to low quality base calls in the 3 ' end of reads, and aligned to hg18 with Bowtie (v.0.12.4) allowing up to three mismatches. Only uniquely mapping reads were kept, and identical reads were collapsed to one read. Because the reads represent the ends of DNA libraries, for the downstream analyses, the reads were extended to represent the average fragment size of the libraries. All sequencing data have been deposited in Gene Expression Omnibus [GEO:GSE27627]. Regions were defined by using SICER (v.1.03). Only regions that were called by using both input and 'no antibody' as a background control with Benjamini corrected false discovery rate $<0.05$ were kept. Finally, only regions called in both antibody hmeDIP-seq experiments were kept and analyzed. Gene ontology analysis was performed using the Genomic Regions Enrichment of Annotations Tool (GREAT) [13]. Published hESC RNA-seq data [9] were used for expression analyses.

\section{Dot blots}

Fully hydroxymethylated DNA was produced by endpoint PCR using Phusion polymerase (NEB, Ipswich, MA, USA) and hm-dCTP (Bioline, Tauton, MA, USA) followed by PCR purification (Qiagen, Valencia, CA, USA). Unmethylated and fully methylated control DNAs were produced in the same manner with dCTP and 
m-dCTP (NEB, Ipswich, MA, USA), respectively. Various amounts of DNA were denatured, snap cooled and dotted onto positively charged nylon membranes (Roche, Indianapolis, IN, USA). Membranes were crosslinked, blocked with 5\% milk, and incubated with Active Motif $(1: 10,000) 5$-hmC antibody for 1 hour. Membranes were washed and then incubated with anti-rabbit secondary horseradish peroxidase-linked antibody (CST, Danvers, MA, USA) for 1 hour, washed, and developed with ECL reagent (CST) and Biomax MS film (Kodak). DNA sequences were (primer sequences in bold):

12 CG-TACTCTATACTCTACTCATCATTACAC GCGCGATATCGTTAACGATAATTCGCGCGATTACGATCGATAACGCGTTAATATGAGATATGAGAT GTGTATG; 6 CG-TACTCTATACTCTACTCATCATTACAATATATATATCGTTAACGATAATTCGCGCG ATTACGATTTATAATTAATTAATATGAGATATGAG ATGTGTATG; 3 CG-TACTCTATACTCTACTC ATCATTACAATATATATATAATTAATTATAATTC GCGAAATTACGATTTATAATTAATTAATATGAGATATGAGATGTGTATG; 1 CG-TACTCTATACTCTACTCATCATTACAATAT ATATATAATTAATTA TAATTAACGAAATTATAATTTATAATTAATTAA TATGAGATATGAGATGTGTATG.

\section{Validation of hydroxymethylated loci using Mspl restriction enzyme and beta-glucosyltransferase} Human stem cell genomic DNA (5 to $10 \mu \mathrm{g}$ ) was treated with the EpiMark 5-hmC and 5-mC Analysis Kit as per the included protocol (NEB). Briefly, DNA was either glucosylated with beta-glucosyltransferase and UDP-Glc or mock treated with beta-glucosyltransferase and no UDP-Glc for 12 to 18 hours. These reactions were then split into three and mock digested, digested with MspI, or with HpaII for at least 4 hours. Samples were treated with proteinase $\mathrm{K}$ that was then heat inactivated. All DNA were diluted to a final concentration of $16 \mathrm{ng} / \mu \mathrm{l}$ to be used for PCR analysis. Quantitative PCR was completed with iQ SYBR Green Supermix (Biorad, Hercules, CA, USA) using a CFX384 Real-Time PCR Detection System (Biorad). Primers used for quantitative PCR are listed in Table $\mathrm{S} 1$ in Additional file 1.

\section{Additional material}

Additional file 1: Supplementary figures and table. Figure S1: $5 \mathrm{hmC}$ dot blots on oligos with varying amounts of $5 \mathrm{hmC}$. Figure S2: characterization of defined $5 \mathrm{hmC}$ peaks. Figure S3: correlation of $5 \mathrm{hmC}$ and gene expression. Figure $54: 5 \mathrm{hmC}$ and different classes of putative enhancers [12]. Figure S5: gene ontology analysis of genes that overlap with $5 \mathrm{hmC}$ peaks [13]. Figure S6: genome-browser views of $5 \mathrm{hmC}$, enhancers and TFBSs $[9,14,15]$. Figure S7: sequence composition over $5 \mathrm{hmC}$ regions in different genomic locations. Table S1: primers used for quantitative $P C R$

\section{Abbreviations}

5hmC: 5-hydroxymethylcytosine; 5mC: 5-methylcytosine; bp: base pair; ESC: embryonic stem cell; H3K4me1: histone H3 mono-methylated at lysine 4; H3K27ac: histone H3 acetylated at lysine 27; hESC: human embryonic stem cell; hmeDIP: hydroxymethyl-DNA immunoprecipitation; RPKM: reads per kilobase per million mapped reads; TFBS: transcription factor binding site.

\section{Acknowledgements}

HS was supported by a Fred Eiserling and Judith Lengyel Graduate Doctoral Fellowship. SF is a Special Fellow of the Leukemia and Lymphoma Society. Research in the laboratory of SEJ was supported by National Institutes of Health grant GM60398 and by an Innovation Award from the Eli and Edythe Broad Center of Regenerative Medicine and Stem Cell Research at UCLA. SEJ is an investigator of the Howard Hughes Medical Institute.

\section{Author details}

${ }^{1}$ Department of Molecular, Cell and Developmental Biology, University of California, Los Angeles, Los Angeles, CA 90095, USA. ${ }^{2}$ Howard Hughes Medical Institute, University of California, Los Angeles, Los Angeles, CA 90095, USA. ${ }^{3}$ New England Biolabs, Inc., 240 County Road, Ipswich, MA 01938, USA

\section{Authors' contributions}

HS, SP and SEJ designed the study. SF and SMK performed the experiments. HS and SEJ analyzed the data. HS wrote the paper.

Received: 10 March 2011 Revised: 28 May 2011

Accepted: 20 June 2011 Published: 20 June 2011

\section{References}

1. Tahiliani M, Koh KP, Shen Y, Pastor WA, Bandukwala H, Brudno Y, Agarwal S, lyer LM, Liu DR, Aravind L, Rao A: Conversion of 5-methylcytosine to 5hydroxymethylcytosine in mammalian DNA by MLL partner TET1. Science 2009, 324:930-935

2. Kriaucionis $\mathrm{S}$, Heintz N: The nuclear DNA base 5-hydroxymethylcytosine is present in Purkinje neurons and the brain. Science 2009, 324:929-930.

3. Ito S, D'Alessio AC, Taranova OV, Hong K, Sowers LC, Zhang Y: Role of Tet proteins in $5 \mathrm{mC}$ to $5 \mathrm{hmC}$ conversion, ES-cell self-renewal and inner cell mass specification. Nature 2010, 466:1129-1133.

4. Meyer C, Kowarz E, Hofmann J, Renneville A, Zuna J, Trka J, Ben Abdelali R, Macintyre E, De Braekeleer E, De Braekeleer M, Delabesse E, de Oliveira MP, Cavé H, Clappier E, van Dongen JJ, Balgobind BV, van den HeuvelEibrink MM, Beverloo HB, Panzer-Grümayer R, Teigler-Schlegel A, Harbott J, Kjeldsen E, Schnittger S, Koehl U, Gruhn B, Heidenreich O, Chan LC, Yip SF, Krzywinski M, Eckert C, Möricke A, et al: New insights to the MLL recombinome of acute leukemias. Leukemia 2009, 23:1490-1499.

5. Viguie F, Aboura A, Bouscary D, Ramond S, Delmer A, Tachdjian G, Marie JP, Casadevall N: Common 4q24 deletion in four cases of hematopoietic malignancy: early stem cell involvement? Leukemia 2005, 19:1411-1415.

6. Valinluck V, Tsai HH, Rogstad DK, Burdzy A, Bird A, Sowers LC: Oxidative damage to methyl-CpG sequences inhibits the binding of the methylCpG binding domain (MBD) of methyl-CpG binding protein 2 (MeCP2). Nucleic Acids Res 2004, 32:4100-4108.

7. Valinluck $V$, Sowers LC: Endogenous cytosine damage products alter the site selectivity of human DNA maintenance methyltransferase DNMT1. Cancer Res 2007, 67:946-950.

8. Song CX, Szulwach KE, Fu Y, Dai Q, Yi C, Li X, Li Y, Chen CH, Zhang W, Jian X, Wang J, Zhang L, Looney TJ, Zhang B, Godley LA, Hicks LM, Lahn BT, Jin $P$, He C: Selective chemical labeling reveals the genome-wide distribution of 5-hydroxymethylcytosine. Nat Biotechnol 2011, 29:68-72.

9. Lister R, Pelizzola M, Dowen RH, Hawkins RD, Hon G, Tonti-Filippini J, Nery JR, Lee L, Ye Z, Ngo QM, Edsall L, Antosiewicz-Bourget J, Stewart R, Ruotti V, Millar AH, Thomson JA, Ren B, Ecker JR: Human DNA methylomes at base resolution show widespread epigenomic differences. Nature 2009, 462:315-322

10. Morey Kinney S, Chin H, Vaisvila R, Bitinaite J, Zheng Y, Esteve P, Feng S,





2011.

11. Heintzman ND, Hon GC, Hawkins RD, Kheradpour P, Stark A, Harp LF, Ye Z, Lee LK, Stuart RK, Ching CW, Ching KA, Antosiewicz-Bourget JE, Liu H, Zhang X, Green RD, Lobanenkov W, Stewart R, Thomson JA, Crawford GE, Kellis $M$, Ren B: Histone modifications at human enhancers reflect global cell-type-specific gene expression. Nature 2009, 459:108-112.

12. Rada-lglesias A, Bajpai R, Swigut T, Brugmann SA, Flynn RA, Wysocka J: A unique chromatin signature uncovers early developmental enhancers in humans. Nature 2011, 470:279-283.

13. McLean CY, Bristor D, Hiller M, Clarke SL, Schaar BT, Lowe CB, Wenger AM, Bejerano G: GREAT improves functional interpretation of cis-regulatory regions. Nat Biotechnol 2010, 28:495-501.

14. Kunarso G, Chia NY, Jeyakani J, Hwang C, Lu X, Chan YS, Ng HH, Bourque G: Transposable elements have rewired the core regulatory network of human embryonic stem cells. Nat Genet 2010, 42:631-634.

15. International Stem Cell Initiative, Adewumi O, Aflatoonian B, AhrlundRichter L, Amit M, Andrews PW, Beighton G, Bello PA, Benvenisty N, Berry LS, Bevan S, Blum B, Brooking J, Chen KG, Choo AB, Churchill GA, Corbel M, Damjanov I, Draper JS, Dvorak P, Emanuelsson K, Fleck RA, Ford A, Gertow K, Gertsenstein M, Gokhale PJ, Hamilton RS, Hampl A, Healy LE, Hovatta O, et al: Characterization of human embryonic stem cell lines by the International Stem Cell Initiative. Nat Biotechnol 2007, 25:803-816.

16. Brodie Of Brodie EB, Nicolay S, Touchon M, Audit B, d'Aubenton-Carafa $Y$, Thermes C, Arneodo A: From DNA sequence analysis to modeling replication in the human genome. Phys Rev Lett 2005, 94:248103.

17. Touchon M, Nicolay S, Audit B, Brodie of Brodie EB, d'Aubenton-Carafa $Y$, Arneodo A, Thermes C: Replication-associated strand asymmetries in mammalian genomes: toward detection of replication origins. Proc Nat Acad Sci USA 2005, 102:9836-9841.

18. Huvet M, Nicolay S, Touchon M, Audit B, d'Aubenton-Carafa Y, Arneodo A, Thermes $C$ : Human gene organization driven by the coordination of replication and transcription. Genome Res 2007, 17:1278-1285.

19. Smagulova F, Gregoretti IV, Brick K, Khil P, Camerini-Otero RD, Petukhova GV: Genome-wide analysis reveals novel molecular features of mouse recombination hotspots. Nature 2011, 472:375-378.

20. Zhang X, Yazaki J, Sundaresan A, Cokus S, Chan SW, Chen H, Henderson IR, Shinn P, Pellegrini M, Jacobsen SE, Ecker JR: Genome-wide high-resolution mapping and functional analysis of DNA methylation in Arabidopsis. Cell 2006, 126:1189-1201.

21. Hawkins RD, Hon GC, Lee LK, Ngo Q, Lister R, Pelizzola M, Edsall LE, Kuan S, Luu Y, Klugman S, Antosiewicz-Bourget J, Ye Z, Espinoza C, Agarwahl S, Shen L, Ruotti V, Wang W, Stewart R, Thomson JA, Ecker JR, Ren B: Distinct epigenomic landscapes of pluripotent and lineage-committed human cells. Cell Stem Cell 2010, 6:479-491.

doi:10.1186/gb-2011-12-6-r54

Cite this article as: Stroud et al:: 5-Hydroxymethylcytosine is associated with enhancers and gene bodies in human embryonic stem cells. Genome Biology 2011 12:R54.

\section{Submit your next manuscript to BioMed Central and take full advantage of:}

- Convenient online submission

- Thorough peer review

- No space constraints or color figure charges

- Immediate publication on acceptance

- Inclusion in PubMed, CAS, Scopus and Google Scholar

- Research which is freely available for redistribution

Submit your manuscript at www.biomedcentral.com/submit 